\title{
História, política e literatura na escrita epistolar de Júlio Cortázar
}

\author{
Adriane Vidal Costa*
}

Resumo: O objetivo do trabalho é mostrar como a prática epistolar de Júlio Cortázar pode ser compreendida como um espaço de criação de redes de sociabilidades intelectuais que permitem relacioná-las com a criação de espaços de discussão sobre projetos literários e editoriais e para reflexôes político-culturais. As correspondências de Cortázar são importantes meios de veiculação de suas ideias políticas no período mais intenso de sua militância: as décadas de 1960 e 1970. Em suas cartas, Cortázar revela sua compreensão sobre o fazer literário, a função social da literatura, o papel do intelectual e ainda reflete sobre sua atividade literária, defende as revoluçôes e o socialismo, bem como condena as ditaduras militares na América Latina. Enfim, suas cartas revelam um escritor comprometido com as grandes transformaçôes literárias e políticas de seu tempo. Para compreendermos a correspondência de Cortázar como meio de construção de sociabilidades político-intelectuais, analisamos parte das correspondências compiladas nos três volumes organizados por Aurora Bernárdez e editados pela Alfaguara em 2000, são eles: Volume I (Cartas, 1937-1963); Volume II (Cartas, 1964-1968); e Volume III (Cartas, 1969-1983).

Palavras-chave: Júlio Cortázar. Correspondências. Sociabilidades intelectuais. Política. Literatura.

\footnotetext{
* Professora adjunta do Departamento de História e do PPG em História da Universidade Federal de Minas Gerais - UFMG. Doutora em História pela mesma instituição. E-mail: adriane.vidal@uol.com.br.
}

Anos 90, Porto Alegre, v. 23, n. 43, p. 153-178, jul. 2016 


\section{Introduçáo: escrita epistolar - objeto de pesquisa e espaço de sociabilidade intelectual}

Em 1962, o escritor argentino Júlio Cortázar (1914-1984) publicou seu livro Histórias de cronópios e de famas, que reúne pequenos contos de realismo fantástico. Num desses contos, que dá nome à obra, Cortázar inventou fascinantes criaturas que se parecem muito com os seres humanos: os cronópios, os famas e as esperanças. $\mathrm{O}$ leitor, na medida em que decifra o conto, descobre por si mesmo o significado desses seres imaginários. Na nossa interpretação, os cronópios são seres sensíveis, críticos e inconformistas. São também escritores, poetas e artistas que não conseguem viver sem criar e fazer arte, que não diferenciam a arte de escrever da arte de viver e que, acima de tudo, adoram imaginar, debater e polemizar.

Náo foi apenas em seus romances ou contos que Cortázar exerceu a "função" de cronópio, em suas correspondências, privadas ou abertas, ele cumpriu seu papel de crítico, de inconformista e de polemista. Cortázar tinha uma enorme disposição para a escrita epistolar, as cartas eram enviadas para uma gama significativa de escritores, críticos literários, cineastas e editores. ${ }^{2}$ Porém, neste trabalho, analisamos somente as correspondências enviadas por Cortázar para o seu editor argentino Francisco Porrúa, para o escritor peruano Mario Vargas Llosa e para o escritor cubano Roberto Fernández Retamar na década de $1960 .^{3}$ A escolha pelas correspondências enviadas ao três intelectuais se justifica pela forma satisfatória com que elas revelam as redes de sociabilidades estabelecidas em um importante momento da vida do escritor argentino. ${ }^{4} \mathrm{O}$ recorte temporal, a década de 1960, explica-se por se tratar de uma década de profícua produção literária e de intensa militância política de Cortázar.

As cartas de Cortázar revelam sua compreensão sobre o fazer literário, a função social da literatura, o papel do intelectual e suas posições políticas sobre revoluçóes e socialismos na América Latina. Por meio do epistolário, o escritor argentino opinava sobre o que ocorria na América Latina, defendia os diretos humanos, condenava as ditaduras militares, discorria sobre exílio e sobre o boom da literatura latino-americana. Além disso, Cortázar indicava textos e manuscritos de diversos escritores latino-americanos para serem publicados em 
importantes revistas e em prestigiadas editoras. Enfim, suas cartas revelam um escritor comprometido com as grandes transformaçóes literárias e políticas de seu tempo. O objetivo do trabalho é mostrar como a prática epistolar de um escritor com grande "capital cultural", 5 como foi Júlio Cortázar, pode ser compreendida como um espaço que cria e revela redes de sociabilidades intelectuais que permitem relacioná-las com a criação de espaços de discussão sobre projetos literários e editoriais e para reflexóes político-culturais na América Latina.

As cartas pessoais, com suas variadas formas, fazem parte dos gêneros discursivos e se mostram como importantes fontes para o trabalho do pesquisador. A escrita epistolar é rica em possibilidades para se compreender a "narrativa de si", principalmente de escritores como Júlio Cortázar que não deixou memórias ou autobiografias. A função básica mais evidente de uma carta é a comunicação escrita entre um emissor e um receptor separados pela distância. Para além dessa função, podemos compreendê-la como "um gesto de escrita" que cria memórias, testemunhos e autobiografias (BOUVET, 2006).

As cartas privadas não são escritas pensando em um público, mas em um correspondente específico, o que não impede que seu conteúdo seja de interesse mais amplo, pelo contrário, elas constituem uma fonte de investigaçáo muito importante que permite compreender, além da subjetividade do indivíduo, a história de uma sociedade (DOLL CASTILLO, 2002). A carta é um documento de relevante valor testemunhal de uma época:

$\mathrm{Na}$ carta, como em outras escrituras do eu (autobiografias, memórias, diários ou livros de viagem), aparece essa primeira pessoa - 'expressão única de quem a escreve' [...] - que, por sua vez, dá testemunho de 'conscientização histórica' [...] porque nela se manifesta a intimidade de quem a escreve e se resignifica o contexto de produção (HINTZE; ZANDANEL, 2012, p. 13).

A carta representa um intento, consciente ou não, de construção do eu, inclusive quando se escreve para construir o outro. $\mathrm{O}$ autobiográfico está constantemente oscilando entre o real e a invenção, entre a experiência vivida e a experiência criada por meio da linguagem. 
Dessa forma, ao usá-lo como fonte de pesquisa, são necessários alguns cuidados. Ângela de Castro Gomes (GOMES, 2004), alerta para o fato de que toda escrita "auto-referencial", como a carta, é marcada por um "efeito de verdade". A legitimidade e autoridade da narrativa epistolar se assentam na subjetividade do emissor, na noção de verdade como sinceridade. A narrativa epistolar não registra "[...] o que realmente aconteceu [...]", nem devemos cobrar isso dela, mas "[...] o que o autor disse que viu, sentiu, experimentou [...]” em relação ao acontecido. Como aponta Marcos Antônio de Moraes (2001, p. 2-3), "[...] a carta atualiza-se invariavelmente como persona e discurso narcísico; a verdade que enuncia - a do sujeito em determinada ocasião, movido por estratégias de sedução - é datada e cambiante."

A carta serve para elogiar, expressar gratidão, manifestar alegria, formular lamentaçôes, conselhos e recomendaçóes; serve também para convocar, exortar, consolar, polemizar, pedir favores, expor juízos, propor projetos, refletir, criticar e confessar. Ela pode expressar a opiniâo de um autor sobre temas diversos: cultura, sociedade, religiấo, literatura, política e economia. A carta difunde ideias e marca posiçóes (MESTRE SANCHIS, 2000). Como veremos, em grande medida, as cartas enviadas por Cortázar eram para intercambiar informaçóes pessoais, literárias, políticas e culturais.

Desse modo, a carta converte-se em um instrumento válido para conhecer náo só a vida de um escritor, mas conhecer, por meio de suas impressóes e representaçóes, a história de uma época. Compreendemos o epistolário de Cortázar como um discurso auto-biográfico (memória e testemunho) a partir do qual podemos (re)construir parte do seu itinerário intelectual, em um momento de grande efervescência política, a década de 1960. Para analisarmos o seu epistolário, é necessário avaliar o estilo (a forma da escrita), o modo de expressão (que pode variar de acordo como o grau de familiaridade e amizade que mantém com seu destinatário e do assunto tratado) e a intencionalidade (sua atitude e seu posicionamento).

Compreendemos o epistolário também como espaço de sociabilidade intelectual e de constituiçóes de redes intelectuais. $\mathrm{O}$ epistolário permite traçarmos parte do itinerário intelectual de Cortázar e mostrar as relaçóes de amizade e de sociabilidade no campo político e cultural. A partir da análise das cartas, podemos traçar a rede de relaçóes 
sociais do escritor: com quais intelectuais se relacionava, a que círculos literários pertencia ou quais frequentava, quais eram suas afinidades políticas e amizades literárias. Como aponta Gisele Venâncio:

A teia da correspondência de um intelectual permite vislumbrar a tessitura de sua rede pessoal e profissional e, através dela, pode-se caracterizar suas práticas de intercâmbio de ideias, de troca de livros e de divulgação de suas opinióes. Esboça-se assim, através da escrita epistolar parte de sua rede de sociabilidade, permitindo a (re) inserção de suas ideias em ambiente social e cultural (VENANCIO, 2003, p. 114).

Por meio da carta, é possível compreender a constituição de redes de contatos e vislumbrar redes de socialização. No momento de sua escrita, a correspondência envolve, além do emissor e destinatário, vários "correspondentes" indiretos que são nomeados, configurando uma rede de relacionamentos em que a carta é, muitas vezes, o único registro. Por isso, "[...] cabe ao pesquisador buscar descortinar os sujeitos [...]" envolvidos na trama epistolar: "Conhecer esses sujeitos permite ao pesquisador traçar um quadro mais amplo das relaçóes estabelecidas entre eles e, desse modo, perceber a carta como parte de uma rede de contatos" (BEZERRA; SILVA, 2010, p. 61). Nas correspondências, circulam nomes, ideias, confissóes, opiniôes, cenas da vida intelectual e relaçóes afetivas, o que as colocam como espaços privilegiados de sociabilidade.

A sociabilidade é compreendida aqui em seu sentindo mais amplo, para além dos marcos das associaçôes formais. A sociabilidade está presente nos espaços da informalidade, como nos cafés, nos salóes, nas festas, nos mercados, nas praças púbicas, no esporte, na música, no mundo do trabalho, nas confrarias, na vida familiar, nos grupos e círculos políticos, e, claro, nas epístolas. São espaços heterogêneos com distintas formas e práticas, mas decididamente de sociabilidade (NAVARRO, 2006). ${ }^{6}$ As diversas formas de sociabilidades e de circulação de ideias podem constituir redes que necessitam para sua existência da densidade da comunicação (DEVÉS-VALDÉS, 2007). O denso epistolário de Cortázar estabeleceu uma rede de sociabilidade intelectual em função de interesses literários, bibliográficos, culturais 
e políticos. Uma rede intelectual com características transnacionais e transatlânticas (América-Europa), haja vista que ele se correspondia, de Paris e de outros lugares, com intelectuais latino-americanos, norte-americanos e europeus.

\section{A correspondência epistolar: escrita ficcional, crítica literária e mercado editorial}

Antes da análise das correspondências, convém traçarmos um breve panorama sobre a trajetória político-intelectual de Cortázar. Desde muito jovem, nutriu-se da literatura francesa: lia Mallarmé, Baudelaire, Lautréamont, Valéry e Cocteau. Não foi por acaso que Cortázar tornou-se, nos anos de 1940, um dos principais tradutores da literatura francesa na Argentina. Em 1951, por não concordar com o peronismo, ${ }^{7}$ foi para Paris. Como tantos outros intelectuais de sua época, sentia uma forte atração por essa cidade. Cortázar evocou seus primeiros anos na capital francesa e afirmou que naquela época a cidade imaginária construída durante tantos anos se somava e superpunha à realidade das ruas e das pessoas. Paris foi transformada em tema literário e em vários textos Cortázar mostrou a cidade como o lugar do fantástico e das tensôes identitárias (SYLVIE, 2005). Talvez por isso, no livro Rayuela, ele afirmou que Paris era uma enorme metáfora (MONTANES, 2006).

O compromisso de Cortázar com a causa socialista deu-se a partir da Revoluçáo Cubana. Foi também a partir dela que o argentino manifestou interesse, de Paris, pela realidade social e política da América Latina. Para Cortázar (1998, p. 22), a vitória da Revoluçáo Cubana e os primeiros anos de governo náo eram simples acontecimentos históricos ou políticos, mas "[...] uma encarnação da causa do homem, como, por fim, ele chegara a conceber e a desejar". A partir do triunfo da Revolução Cubana, Cortázar buscou "[...] uma via menos alienante da história, adquirindo uma filiação política cada vez mais pronunciada." Essa chave de acesso a toda América Latina levou-o a pronunciar-se explicitamente a favor da revolução e do socialismo. 
Em 1963, Cortázar fez sua primeira viagem a Cuba para ser jurado do concurso literário da revista Casa de las Américas. Na ilha, aceitou, com entusiasmo, o convite para participar do Conselho de Redação da revista, cargo que encarou com bastante seriedade e profissionalismo. Como membro do Conselho, Cortázar foi um dos escritores mais produtivos: dava opinióes sobre a qualidade das ediçôes, preocupava-se com a divulgação, recomendava textos, indicava algum novo membro para ser jurado do Prêmio concedido pela revista (MOREJÓN ARNAIZ, 2004). Em fins da década de 1960, a Revolução Cubana deixou de contar com o "apoio entusiasta" de grande parte da intelectualidade de esquerda, por várias razóes: o forte alinhamento de Cuba com a URSS, moldando o modelo cubano ao chamado socialismo realmente existente; as acusaçôes sobre os rumos equivocados da revolução - perseguiçôes, torturas, prisóes e censura e o polêmico "caso Padilla". ${ }^{8}$ Foram, enfim, os dias em que as questóes políticas convocavam alianças solidárias e desavenças, proclamaçôes e distanciamentos. Cortázar refletiu sobre tudo isso, mas continuou ao lado de Cuba e, na década de 1970, passou a apoiar incondicionalmente a Revolução Sandinista na Nicarágua (COSTA, 2013).

Com Francisco Porrúa, seu editor de 1960 a 1968, conhecido como Paco, Cortázar manteve um longo período de correspondência. Como assessor da editora argentina Sudamericana, Porrúa lia e recomendava para a edição os livros de Cortázar. Ele foi o responsável pela publicação de importantes obras do escritor argentino na década de 1960, como Los premios (1960), Historias de cronopios y de famas (1962) e Rayuela (1963). Porrúa, com o passar dos anos, como demonstra as cartas, tornava-se cada vez mais íntimo de Cortázar e transformava-se em um grande amigo, também chamado de "querido Cronópio”. Uma das primeiras correspondências que Cortázar lhe enviou foi escrita em cinco de março de 1960, mas conheceram-se pessoalmente somente em 1962, fato que não impediu o estreitamento de laços fraternos entre eles. Apesar da amizade, a relação editor-autor sempre esteve presente, como apontou Cortázar (2000, p. 665): “[...] eu não sei quando chegará o dia em que lhe escreverei uma carta que não tenha relação com meus livros".

Desde o início da relação, Cortázar valorizava a opinião de Porrúa e o considerava "un crítico sin concesiones". Compartilhava com ele 
suas dúvidas e angústias de escritor e discutia o conteúdo, a estética e a organizaçáo de suas obras. As cartas que trocava com seu agente literário revelam os cuidados e as obsessóes de um escritor detalhista: a insistência em revisar por mais de uma vez as provas finais de seus livros, as preocupaçóes frequentes com a criação e finalização das capas, a insistência em estabelecer contatos com editoras estrangeiras e em escolher seus tradutores. Enfim, as cartas revelam um escritor extremamente cuidadoso com todo o processo de ediçáo de seus livros.

As correspondências mostram também um escritor preocupado com a recepção de sua obra e com a crítica especializada. Cortázar sempre requisitava a Porrúa que lhe enviasse recortes com notas, resenhas críticas e comentários que saíam nas principais revistas e nos jornais da América Latina. Algumas revistas, inclusive, foram importantes para a divulgação e a promoção de sua obra, pois apontavam a qualidade literária de Cortázar e a originalidade de seus contos. Como foi o caso da revista argentina Primera Plana, o semanário uruguaio Marcha e a revista mexicana Diálogos. Cortázar deixava transparecer em vários momentos seu regozijo ao receber elogios consagratórios, mas, por outro lado, sempre ressaltava sua admiração e preferência pelas críticas mais profundas e solidamente construídas a ponto de manter importante intercambio epistolar com alguns daqueles que as produziram, como Graciela Sola, Ana María Barrenechea, Héctor Schmuder, Saúl Yurkievich, Jaime Alazraki, Saúl Sosnowski (DE DIEGO, 2009).

Nas cartas endereçadas a Porrúa, Cortázar sempre tecia comentários sobre as obras de seus colegas de ofício e pedia a seu editor que lhe enviasse livros recém-publicados na Argentina. Os escritores que mais aparecem nas correspondências enviadas a Porrúa são: Carlos Fuentes, Jorge Luis Borges, Adolfo Bioy Casares, Ernesto Sábato, Tomás Eloy Martínez, Mario Vargas Llosa, Gabriel García Márquez, José Lezama Lima.

Nas correspondências enviadas para Porrúa, além de elogiar a obra do escritor mexicano Carlos Fuentes, ele sempre mencionava a ajuda do escritor mexicano na promoção de sua obra. Como um ciclo de conferências que Carlos Fuentes proferiu sobre ele na BBC. Cortázar narrou em missiva que o impacto das conferências foi positivo e imediato, tanto que J. M. Cohen, especialista em literatura hispano-americana na Inglaterra, e que havia assistido às conferências, pediu 
ao escritor argentino que lhe enviasse todos os seus livros. Cortázar mostrou-se interessadíssimo, pois via aí a oportunidade de ter suas obras publicadas em inglês. Em uma carta, Cortázar (2000b, p. 667) manifestou seu interesse a Porrúa:

[...] seria magnífico se algum editor de lá publicasse um tomo de meus contos ou Rayuela [...] Lhe peço: faça com que a Sudamericana mande minhas coisas a Mr. J. M. Cohen. Fuentes me disse que Cohen é o crítico de literatura espanhola do Sunday Times e é o contato de primeira ordem para a publicação de meus trabalhos na Inglaterra.

O esforço foi frutífero, tempos depois, Cortázar teve seus contos e Rayuela publicados em inglês pela Editorial Pantheon por intermédio de L. M. Cohen.

Nas correspondências com Porrúa, Cortázar (2000b, p. 789-790) fez poucas referências ao escritor argentino Jorge Luiz Borges, mas sempre com muita admiração e reconhecimento. Contou que se encontrou com Borges na sede da Unesco em 1964: "[...] quando dei por mim [...] já estávamos nos abraçando, o que me deixou sem palavras." Cortázar recordava com orgulho e gratidão que a publicação de seu conto, $A$ casa tomada, na revista Anales, em 1946, foi feita por intermédio de Borges que, naquele momento, nem o conhecia pessoalmente. Segundo seus críticos, e o próprio Cortázar, foi tal gesto de Borges que o tornou conhecido na Argentina naquela época. Depois do encontro emocionado com o autor de Funes o memorioso, Cortázar foi ouvi-lo em uma conferência sobre literatura fantástica que o deixou "mirando estrelas". No final, conforme Cortázar, os jornalistas fizeram de tudo para arrancar uma ou duas palavras sobre política de Borges, missáo possível. Cortázar pontuou: "pouco me importa". A obra de Borges bastava-lhe.

Cortázar (2000a, p. 479) admirava também o escritor argentino Adolfo Bioy Casares e acompanhava de perto suas publicaçóes. Porém, com outro escritor argentino, Ernesto Sábato, Cortázar foi ácido em diversos momentos. Em cartas destinadas a Porrúa, fez vários comentários jocosos e amargos sobre ele: 
[...] minha impressão é que o homem está completamente louco. O livro [Sobre héroes y tumbas] parece uma espécie de folhetim, porém sem a mesma qualidade de um bom Ponson du terrail ${ }^{9}$. Me assombra que alguns amigos portenhos tenham dito que se tratava de 'um livro importante'. A importância, na Argentina, está ficando irrespirável.

Em outra missiva enviada em maio de 1966, Cortázar (2000b, p. 1018), ao rebater uma crítica de Sábato, chegou a ser deselegante em seus comentários:

Outra noite Mario Benedetti me contou em Paris que o moleque Ernesto havia dito que eu tinha um estilo feminino que lhe recordava a Katherine Mansfield. Se for certo (se eu tiver um estilo semelhante) eu consideraria um elogio; mas já se sabe que lá, junto ao rio imóvel, há que escrever como macho ou tu não vales nada. Pensar que se o moleque Ernesto chegasse alguma vez a escrever apenas uma página como Simone de Beauvoir ou Christine Rochefort, estaria salvo para a literatura...

Talvez Cortázar (2000b, p. 788) tenha agido assim por usar como meio de expressáo uma correspondência privada. De qualquer modo, isso mostra-nos que as relações entre os escritores não eram baseadas somente em cordialidades ou amabilidades. Cortázar também deixou transparecer certo descontentamento com outro argentino, o escritor e jornalista Tomás Eloy Martínez, na época, editor-chefe da revista Primera Plana. ${ }^{10}$ Em 1964, depois da insistência de seu editor, Cortázar decidiu conceder uma entrevista a Primeira Plana, em retribuição "a generosidade com" que a revista promovia "seus livros". Quem realizou a entrevista, transformada posteriormente em artigo, Las figuras del zodiaco, foi Tomás Eloy Martínez que, quando publicou o texto, no n. 173, omitiu, para desgosto de Cortázar, a informação sobre sua primeira viagem a Cuba. Quando leu o artigo, escreveu a Porrúa extremamente contrariado: "A omissão da viagem a Cuba foi idiota". 
Cortázar (2000b, p. 859) não esqueceu o ocorrido, e em carta endereçada a Tomás Eloy Martínez, em 1965, relembrou o episódio e negou de forma irônica o convite da Primera Plana para participar de um concurso literário: Cortázar alegou que não poderia aceitar o convite da revista argentina porque estava muito ocupado com seu fazer literário. $\mathrm{Na}$ carta, afirmou:

Permita-me, Tomás, adivinhar-lhe o pensamento por um momento. Eu sei que você, ao ler os parágrafos anteriores [da carta], pensou, mas ele participou como jurado do concurso da Casa de las Américas. Porém essa exceção, de que não me arrependo, obedeceu a razóes que iam mais além da literatura. Cada um ajuda como pode aquilo que ama.

O trecho da carta revela uma postura política assumida publicamente por Cortázar que extrapolava o ambiente das correspondências privadas.

Cortázar manteve relaçóes próximas com o escritor peruano Mario Vargas Llosa, com quem possuía afinidades literárias e políticas, pelo menos até fins da década de 1960. Vargas Llosa enviava manuscritos de seus livros para Cortázar ler, que, por sua vez, lia e dava sugestôes pertinentes por meio de correspondências. Cortázar, admirador da obra de Vargas Llosa, comportava-se como um verdadeiro crítico literário ao opinar sobre os livros do amigo. Em 1962, Cortázar enviou uma breve carta para Vargas Llosa na qual lhe informava que acabara de ler os manuscritos de Los impostores e que estava profundamente comovido com a qualidade literária da obra. Em carta endereçada ao mexicano Joaquín Díez Canedo, editor da Joaquín Motriz e da Fondo de Cultura Económica, Cortázar escreveu (2000a, p. 492):

Faz alguns dias que li os originais de uma excelente romance de Mario Vargas, jovem escritor peruano que ganhou faz uns três anos um prêmio na Espanha por seu livro Los jefes. Radicado em Paris, Vargas terminou a pouco seu último romance que se intitula Los impostores [La ciudady los perros]. Admiravelmente escrita, conta a vida de um grupo de estudantes limenhos em um colégio militar. É um livro de 
uma violência, de uma força nada comum em nossos países [...]. Creio que Los impostores será um dos melhores romances dos últimos anos (e não penso somente na América Latina). ${ }^{11}$

Cortázar e Vargas Llosa, assim como Carlos Fuentes e também Gabriel García Márquez, foram os principais escritores do chamado boom da literatura latino-americana. ${ }^{12}$ Por meio da análise do epistolário de Cortázar, é possível perceber que esses escritores - e outros mais - formavam um grupo coeso que agia conjuntamente, trocando correspondências e indicando textos e obras uns dos outros para publicaçôes. Como aponta Claudia Gilman, esse grupo, que entendemos formar uma rede, caracterizou-se por organizar uma forte trama de relaçóes pessoais entre escritores e críticos latino-americanos, trama suficientemente poderosa para produzir alianças, divergências e efeitos sobre as modalidades da crítica profissional e, inclusive, sobre as consagraçôes literárias. Nessa direção, comentou Rodríquez Monegal (1966, p. 62-72): “[...] as estrelas de romances como García Márquez e Vargas Llosa ainda não se conheciam, mas já trocavam correspondências. Mario foi um dos promotores mais constantes de Cien años de soledad". O crítico uruguaio dedicou, em 1966, um elogioso e denso artigo a Mario Vargas Llosa e à sua obra - especificamente La ciudad y los perros -, no qual o colocava como um dos mais ardentes criadores da América e exemplo de escritor completamente dedicado à sua vocaçáo. Em uma reportagem, Carlos Fuentes (MACADAM; RUAS, 1996, p. 134) afirmou que havia ocorrido algo extraordinário na vida literária hispano-americana: "[...] todas as figuras proeminentes do boom eram amigas entre si". Além disso, Carlos Fuentes dedicou os livros La muerte de Artemio Cruze Cambio de piel para Cortázar, e seu ensaio, Fortuna lo que ha querido, para García Márquez, que, por sua vez, em Cien años de soledad agradeceu os favores recebidos de vários colegas escritores e críticos literários.

Pouco tempo depois, Carlos Fuentes enviou para Cortázar as primeiras oitenta páginas de Cien años de soledad. Cortázar (2000b, p. 1072) leu com grande entusiasmo e em carta endereçada a Francisco Porrúa, elogiou a editora Sudamericana pela decisão de publicar o livro de García Márquez, que possuía uma "prosa tão viva, táo caliente e tâo fabulosamente inventiva". Aproveitou o 
ensejo para recomendar a publicação do livro Cambio de piel, de Carlos Fuentes. Como se não bastasse, Fuentes também enviou o segundo capítulo de Cien años de soledad para que Rodríquez Monegal o publicasse na revista Mundo Nuevo em março de 1967, com o título de El insomnio en Macondo. Porém, antes disso, parte da obra já havia sido publicada por amigos de García Márquez no El Espectador, de Bogotá. Além dessas duas publicaçóes, fragmentos do romance foram divulgados em outros importantes periódicos, como na revista Amaru, de Lima, que, além de trechos inéditos, publicou também uma crítica elogiosa na qual se lia: "[...] a fama já ilumina esse notável jovem escritor e acredita-se que ele possa ser um dos grandes romancistas latino-americanos surgidos nos últimos dez anos". Em Marcha, foram publicados trechos da obra com o título Diluvio en Macondo, acompanhados de um comentário que se referia ao romance como o mais esperado do ano. Apareceram também fragmentos do romance nas revistas Eco, de Bogotá, e Diálogos, do México (SALDÍVAR, 2000). Enfim, tudo isso criou uma imensa expectativa em torno do livro. $\mathrm{Na}$ verdade, como afirmou Vargas Llosa (1971), a sua consagração começou antes mesmo de seu lançamento. Nesse sentido, segundo Claudia Gilman (2003, p. 96), o êxito de Cien años de soledad também se explica pelo “[...] fenômeno de consagração horizontal mais importante que se teve notícia na América Latina.”

\section{O debate sobre o engajamento político na escrita epistolar de Cortázar}

Além das correspondências de cunho literário e editorial, Cortázar (2000b, p. 1278) enviou para Vargas Llosa algumas cartas com explícito conteúdo político. Como já apontamos, em 1968, Cortázar viajou para Cuba para participar do I Congresso Cultural de la Habana, período em que começava um intenso controle político sobre o meio cultural na ilha. Cortázar expressava uma grande preocupação em relação à situação dos intelectuais em Cuba. Em três de novembro de 1968, enviou para Vargas Llosa uma correspondência, comunicandolhe que pretendia escrever uma carta "privada" para Fidel Castro, 
para pedir-lhe explicações sobre os problemas com os intelectuais em Cuba. No final da carta, pediu o apoio do escritor peruano e fez uma observação: "Guarda total reserva sobre isso. É um assunto restrito tratado diretamente com Fidel, para evitar a publicidade, que é inútil e contraproducente". (grifos do autor)

No mês seguinte, enviou nova correspondência para Vargas Llosa, agora com a mencionada carta em anexo, na qual pedia mais explicaçóes ao governo cubano sobre o que de fato acontecia na ilha, sobretudo com Padilla. Explicava a Vargas Llosa que essa carta havia sido escrita por ele, Carlos Fuentes e Juan Goytisolo, com base em "[...] informaçôes fidedignas que receberam". ${ }^{13}$ De maneira alguma ela deveria ser uma carta aberta, mas um pedido de informaçôes que contasse com a assinatura de poucos escritores amigos de Cuba, dentre eles Vargas Llosa e García Márquez, que também receberia uma cópia da carta. Cortázar acreditava que as coisas na ilha estavam “[...] bastante graves para que ficassem calados”. Por isso, pretendia enviar a carta a Fidel Castro de maneira oficial, por meio da Embaixada Cubana em Paris, e com cópias para Raúl Roa, Haydée Santamaría, Osvaldo Dorticós e Célia Sánchez. Segundo Cortázar (2000b, p. 1287) “[...] objetivo seria fazer conhecer suficientemente, entre as pessoas-chave, nossas inquietudes e conseguir uma resposta em breve [...]". ${ }^{14}$ Não sabemos se essa carta realmente chegou a Cuba. Cortázar não fez mais nenhuma menção a ela no seu epistolário nem em outros meios. Contudo, a resposta a suas inquietaçóes foi dada in loco.

Em janeiro de 1969, Cortázar viajou a Havana, com o intuito de participar da reunião da revista Casa de las Américas. Quem não apareceu foi Vargas Llosa, que, como membro do Comitê da revista, também havia sido convidado. Quando retornou a Paris, no final daquele mês, Cortázar escreveu para Vargas Llosa ${ }^{15}$, dizendo que os membros da revista não haviam gostado de sua ausência sem justificativa e o repreendiam severamente pelo artigo El socialismo y los tanques (1968) — no qual condenava o apoio de Fidel Castro aos soviéticos quando esses invadiram a Tchecoslováquia. Cortázar (2000c, p. 1327-1328) afirmava na carta que Vargas Llosa tinha todo o direito de condenar a invasão soviética, inclusive ele mesmo havia assinado várias mensagens de protesto e passado oito dias em Praga depois do ocorrido. O problema era que em Havana eles não gostaram 
das frases com as quais Vargas Llosa criticou o apoio de Fidel Castro à URSS, isso era inadmissível por parte de alguém que, "[...] frente aos problemas críticos da revolução (o Congresso Cultural em Havana, primeiro, e agora a reunião da revista), permanecia ausente por razóes de trabalho no primeiro caso e sem dar explicação alguma no segundo". Cortázar contou a Vargas Llosa na carta sobre a situação dos intelectuais na ilha, que, de fato, havia ocorrido momento de intimidação, mas que, durante uma longa conversa com Haydée Santamaría, ela mostrou que ele "[...] estava sendo mal informado sobre muitas coisas que aconteciam em Cuba e que a partir da Europa era muito fácil formar uma consciência a base de telegramas e declaraçóes”. O clima tinha melhorado na ilha, por isso acreditava que os incidentes do tipo Padilla não se repetiriam tão cedo. Cortázar acrescentou que a função do intelectual estrangeiro, importante e necessária, era a de levar até Cuba uma visão mais universal das coisas e não de serem fiscais da Revolução, como havia proposto o jornal Verde Olivo, órgão das Fuerzas Armadas Revolucionarias. Cortázar finalizou a carta confessando que nunca se arrependeria de ter ido a Havana, e se houvesse novos incidentes voltaria, porque era a única maneira que tinha de estar com a Revolução, que, apesar dos seus vaivéns, fora o acontecimento mais importante dos últimos anos na América Latina.

Em março de 1969, Cortázar enviou outra carta a Vargas Llosa na tentativa de convencê-lo a ir a Havana e a se reconciliar com os membros da Casa de las Américas. Cortázar afirmou que os motivos que Vargas Llosa dera para sua ausência na reunião do Comitê como ter-se enganado com as datas - não eram convincentes nem definitivos. Cortázar (2000c, p. 1335) disse a Vargas Llosa que, no fundo, o motivo de sua ausência na reunião do Comitê era a sua desilusão com a Revolução, e, por essa razão, não tinha interesse no que acontecia em Cuba. Cortázar concordava que a Revolução cometia alguns desvios, como o "caso Padilla", mas que apesar de tudo "[...] nossa solidariedade com o essencial da revolução segue sendo o melhor que podemos dar à América Latina depois de nossos livros". Por isso, pedia a Vargas Llosa que fosse a Havana para dissipar as dúvidas e os equívocos.

Cortázar concordou plenamente com as críticas que os cubanos fizeram a Vargas Llosa por ter aceitado o convite para ser professor 
visitante na universidade norte-americana Pullman. E declarou que se Vargas Llosa tivesse participado do Congresso Cultural de la Habana, no qual esse tema foi exaustivamente debatido, ele jamais teria aceitado o convite. Inclusive, ele havia recusado um convite dessa natureza feito pela Universidade de Columbia, pois mesmo que tivesse excelentes condiçốes de trabalho e liberdade de expressão isso significaria ceder às pressôes ianques e a seus agrados e bajulaçôes. ${ }^{16}$ Por outro lado, Cortázar confessou a Vargas Llosa que também poderia ter problemas com os cubanos por sua entrevista à revista Life, que sairia em breve. Explicou que havia se metido em "território inimigo" porque era um meio de fazer com que suas ideias políticas chegassem a um número maior de pessoas, as quais não tinham acesso a revista Casa ou a qualquer outra revista para a qual ele escrevia. Ainda assim, Cortázar (2000c, p. 1336) presumia que seria mal interpretado e julgado, porque "[...] a radicalização em Cuba é muito forte, há uma espécie de exasperação que de um lado possibilita esplêndidos resultados no setor econômico, porém de outro situa os escritores em um maniqueísmo cada vez mais simplificador". Em 1970, em carta enviada a Fernández Retamar, Cortázar (2000c, p. 1408-1409) revelou seus esforços para reaproximar Vargas Llosa da Revolução Cubana. O seu principal argumento para tentar convencer seu amigo, cada vez mais distante de Cuba, foi explicar-lhe que era possível conciliar socialismo com liberdade e cultura. Como sabemos, seus esforços foram em vão, pois Vargas Llosa foi se distanciando cada vez mais de Cuba e a amizade entre eles foi, de certa forma, abalada. Em certa ocasião, Vargas Llosa comentou sobre isso:

[...] fizemos viagens juntos a Cuba, compartilhamos inclusive muitas dúvidas e reservas [em relação a Cuba] num dado momento, e depois se produziu um distanciamento político com Julio porque optamos por posiçóes diferentes e discrepantes. Mas a amizade nunca se cortou. Sempre a mantivemos. Eu não lhe pedi nunca nem o carinho nem o respeito, porque creio que Julio foi sempre uma pessoa muito... creio que ingênua, não apenas equivocada, mas ingênua em suas tomadas de posição política, mas ao mesmo tempo foi sempre de uma grande autenticidade (SETTI, 1986, p. 31). 
Na década de 1960, Cortázar manteve extensa correspondência com escritores cubanos. ${ }^{17}$ Sua primeira correspondência foi para Antón Arrufat em 1963, depois de sua primeira viagem a Cuba. Na época, Arrufat era o diretor da revista ${ }^{18}$ Casa de las Américas e foi em torno da revista que a amizade entre os dois começou e, como já indicamos, o escritor argentino era membro do Conselho Editorial da revista e jurado concurso literário organizado por ela. Foi para Arrufat que Cortázar (2000a, p. 542) narrou em carta as suas primeiras impressóes sobre a ilha: "[...] tudo em Cuba era demasiado vivo, demasiado quente, demasiado intenso". A comparação com a Europa foi inevitável, parecia-se com "um cubo de cristal." E dentro dela Cortázar se "[...] movia penosamente, buscando um ar menos geométrico e pessoas menos cartesianas." Além disso, como sempre fazia, pedia a Arrufat que lhe enviasse revistas e livros de Cuba. Cortázar (2000a, p. 631-632) expressava em suas correspondências uma ânsia enorme de conhecer tudo sobre Cuba e os cubanos. A sua relação com Cuba era tão intensa que, autorizou a revelia de Porrúa e da Sudamericana, que os cubanos fizessem uma antologia de seus contos: "[...] com alegria, com orgulho, com toda a minha alma lhes digo que sim, que autorizo e apoio". Cortázar pedia reservas sobre isso e afirmava: "[...] fica entendido que em caso de ocorrer algum problema, estou disposto a assumir toda a responsabilidade."

\section{A correspondência epistolar com Roberto Fernández Retamar: o escritor latino-americano e a funçáo político-social da literatura}

Com Roberto Fernández Retamar, Cortázar manteve uma correspondência duradoura. Em 1967, Cortázar (2000b, p. 1133-1135) endereçou a Fernández Retamar uma de suas principais cartas em termos de reflexóes políticas, que foi publicada na revista Casa de las Américas. A carta foi resultado de uma solicitação de Fernández Retamar para que Cortázar desse a sua opinião sobre a situação do intelectual latino-americano após a Revolução Cubana. A reflexão de Cortázar girou, obviamente, em torno de sua própria especificidade de escritor latino-americano instalado na Europa, e das repercussóes 
dessa condição em sua obra e na forma como ele se posicionava frente à literatura latino-americana. Logo no início da missiva, Cortázar assumiu sua condição de intelectual latino-americano e, ao mesmo tempo, fez uma ressalva: que essa condição não invalidava o fato "deliberado e irreversível" de ter escolhido residir num país europeu por sua "[...] soberana vontade de viver e escrever da maneira [...]" que lhe parecesse "mais plena e satisfatória". O que o estimulou ou impulsionou a reiniciar "um contato pessoal com a América Latina", depois de anos no exílio, foi a aproximação com Cuba. O contato de Cortázar com a Revolução, além da amizade e do diálogo com escritores e artistas cubanos agiram "duplamente" nele, causando, e, por um lado, uma proximidade maior com a realidade latino-americana, da qual se sentia afastado, por outro, levou-o a assistir cotidianamente "à dura e desesperadora tarefa" dos cubanos para "[...] edificar o socialismo num país tâo pouco preparado em muitos aspectos e tão aberto a riscos iminentes".

Segundo Cortázar (2000b, p. 1135), caso ele tivesse que enumerar os bons motivos para ter saído do seu país, o principal seria "[...] o fato de ter acompanhado da Europa, com uma visão desnacionalizada, a Revolução Cubana”. Essa convicção explicava-se pelo contato que ele tinha com os argentinos que estavam de passagem por Paris, pois eles tinham "[...] a mais triste ignorância do que verdadeiramente estava acontecendo em Cuba". Isso ocorria, em grande medida, pela influência que a informação norte-americana exercia em seu país. Quase ninguém estava a salvo dessa influência, uma "infinidade de escritores e artistas" comungavam "[...] com as engrenagens subliminares da United Press e das revistas 'democráticas' que marchavam ao compasso da Times ou da Life".

Cortázar (2000b, p. 1134-1135) confessou a Fernández Retamar que assumir a condição de intelectual latino-americano vivendo em Paris era paradoxal, um paradoxo que apontava para uma questáo mais profunda, qual seja:

A necessidade de situar-se na perspectiva mais universal do Velho Mundo, de onde tudo parece abarcável numa espécie de ubiquidade mental, para ir descobrindo pouco a pouco as verdadeiras raízes latino-americanas, sem por isto perder a 
visão global da história e do homem. A idade e a maturidade naturalmente influem, mas náo bastam para explicar este processo de reconciliação e recuperação de valores originais; insisto em pensar [...] que, se houvesse ficado na Argentina, a minha maturidade de escritor ter-se-ia traduzindo-se de outra maneira, provavelmente mais perfeita e satisfatória para os historiadores da literatura, mas certamente menos incitante, provocativa e em última instância fraternal para aqueles que leem os meus livros por razóes vitais e não visando a ficha bibliográfica ou a classificação estética.

O argumento de Cortázar (2000b, p. 1135, grifos nossos) era de que a distância territorial promovia benefícios em prol de uma melhor contemplação e de um entendimento da realidade latino-americana, e que por isso a sua literatura possuía uma raiz nacional e regional potencializada por uma experiência mais aberta e mais complexa. Nessa direção, o escritor, afastado de seu país, colocavase forçosamente numa perspectiva diferente, pois estava sempre à margem da circunstância local, "[...] sem a inevitável dialética do challenge and response cotidianos representados pelos problemas políticos, econômicos ou sociais do país [...]", que exigiam do escritor o compromisso "imediato e consciente". Porém, a compreensão que o escritor exilado tinha "do processo humano" era mais abrangente, o que o levava a "operar por conjuntos e por sínteses", sem se perder em contextos imediatos. A distância propiciava ao escritor "uma lucidez às vezes insuportável, mas sempre esclarecedora". De maneira que os intelectuais submetidos a condicionamentos que lhes impunham o afastamento, agiam, "[...] por assim dizer de fora para dentro, partindo de ideias e princípios universais para depois circunscrevê-los a um país, a um idioma, a uma maneira de ser".

As noçóes de universalidade e internacionalismo - por oposição ao regionalismo, que implicava muitas vezes fragmentação, localismo, especificidade e nacionalismo - formaram parte da retórica da esquerda cultural dos anos de 1960. Nesse sentido, a cultura era concebida como um espaço integrado e participativo capaz de promover e produzir visóes de conjunto, organizadas a partir de grandes paradigmas filosóficos da modernidade. Assim, o ideal presente nas reflexões de Cortázar 
carregava um conceito de história universal não muito distante de uma visão eurocentrista, presente na América Latina desde a organização dos Estados nacionais (MORAÑA, p. 103-120). Contudo, mesmo defendendo práticas mais universalistas para a literatura, Cortázar (2000b, p. 1137, grifos do autor) afirmava não acreditar

[...] nos universalismos diluídos e teóricos, nas 'cidadanias do mundo' entendidas como meio para escapar às responsabilidades imediatas e concretas — Vietná, Cuba, toda a América Latina - em nome de um universalismo mais cômodo por ser menos perigoso; no entanto, minha própria situação pessoal me inclina a participar do que acontece com todos, a escutar as vozes que entram por qualquer quadrante da rosa-dos-ventos.

Cortázar assumiu sua condição de escritor latino-americano, mas não se considerava um grande exemplo da "volta às origens", por conseguinte sua obra não expressava tão somente formas telúricas e nacionais. As formas nacionais e telúricas, segundo ele, eram características presentes em uma corrente importante da literatura latino-americana, representada por romances como Os passos perdidos (Alejo Carpentier) e, mais circunscritamente, Doña Bárbara (Rómulo Gallegos). Cortázar (2000b, p. 1135-1136) definiu o telurismo como "[...] profundamente alheio por ser estreito, paroquial e até provinciano". Uma literatura telúrica, conforme ele, não expressava uma visão totalizadora da cultura e da história, pois os escritores que a praticavam concentravam todo o seu talento em um trabalho "de área", e isso parecia-lhe "[...] um preâmbulo aos piores avanços do nacionalismo negativo quando se transforma no credo dos escritores que, quase sempre por carências culturais, teimam em exaltar os valores da terrinha contra os valores [...]" mais universais. Assim, o paradoxo de redescobrir o latino-americano à distância encerrava, para Cortázar, um processo de ordem completamente diferente de "[...] uma volta arrependida e sentimental à terrinha”. Cortázar não pretendia voltar “à terrinha”, considerava a França a sua casa, como o lugar preferencial para um temperamento como o seu, para os seus gostos e para escrever, antes de “[...] dedicar-se à velhice”. 
A carta de Cortázar publicada na revista rendeu uma das principais polêmicas intelectuais na América Latina no século XX. Apesar de Cortázar náo ter citado nominalmente Arguedas - que fazia uma literatura voltada para temas indigenistas, enraizada no telurismo andino e nutrida por tradiçóes e mitos autóctones - , quando o escritor peruano leu a carta publicada em Casa de las Américas, a entendeu como se fosse um ataque pessoal, principalmente no que tange às críticas de Cortázar ao telurismo na literatura. A resposta de Arguedas veio com a publicação de um pequeno texto na revista peruana Amaru (abril-junho de 1968), ${ }^{19}$ no qual ele expressou todo o seu descontentamento ao expor suas convicções em torno da tarefa do escritor: escrever romances não era ofício, o escritor escreve romances por amor, necessidade, prazer, mas náo por ofício, ao mesmo tempo em que colocava em evidência a lógica mercantilista do boom na literatura latino-americana. Arguedas (1983) assumiu de forma irônica a sua condição de escritor provinciano ao afirmar que entendia provincianamente o sentido da palavra ofício: representava uma técnica que se aprende e exerce especificamente para ganar plata. Escrever novela visando apenas à sua vendagem e ao lucro lhe parecia coisa de gente muito preocupada com o "universo das especializaçóes". Polêmica que se intensificou depois da entrevista que Cortázar concedeu à revista Life em $1969 .^{20}$

\section{Consideraçóes finais}

Enfim, por mais subjetiva que seja a escrita epistolar, é na correspondência com o outro que se constrói a "escrita de si". A correspondência constitui-se como locus privilegiado não apenas para a escrita autorreferencial, mas para traçar redes de sociabilidades intelectuais. O epistolário de Cortázar é exemplar nesse sentido. Em 1940, Cortázar (2000a, p. 95) profetizou: “[...] sei que quando eu morrer (de algum modo raro certamente) vocês meus amigos publicarão minhas obras completas e, em belos apêndices, agregarão minhas copiosas correspondências". ${ }^{21}$ Mais do que copiosas e "belos apêndices", as correspondências de Cortázar merecem destaque no conjunto de sua obra, são obras-primas. 


\section{HISTORY, POLITICS AND LITERATURE IN JÚLIO CORTÁZAR'S EPISTOLARY WRITING}

Abstract: The aim of this paper is to reveal how Julio Cortazar's epistolary practice can be understood as a breeding space of intellectual sociability networks that allow to relate them to the creation of discussion forums on literary and publishing projects and political-cultural reflections. Cortázar's correspondences are important means of propagation of his political views in the most intense period of his activism: 1960 and 1970. In his letters, Cortázar reveals his understanding of the literary work, the social function of literature, the role of the intellectual and still reflects on his literary activity, defends revolutions and socialism and condemn the military dictatorships in Latin America. Ultimately, his letters reveal a committed writer with the great literary and political transformations of his time. To understand Cortázar's correspondence as a means of construction of political and intellectual sociability, we analyze part of his correspondence compiled in three volumes organized by Aurora Bernardez and published by Alfaguara in 2000, they are: Volume I (Letters, 1937-1963); Volume II (Letters, 1964-1968); and Volume III (Letters, 1969-1983).

Keywords: Júlio Cortázar. Correspondence. Intellectual sociability. Politics. Literature.

\section{Notas}

${ }^{1}$ Cortázar, um compulsivo missivista, correspondeu-se com um número considerável de intelectuais: Gabriel García Márquez, Mario Vargas Llosa, Francisco Porrúa, Antón Arrufat, Roberto Fernández Retamar, Paul Blackburn, Jean Andreu, Manuel Antín, Sara Facio, Gregory Rabassa e muitos outros.

${ }^{2}$ Como não tivemos acesso às cartas que Cortázar recebia dos seus destinatários, analisamos somente as que o escritor enviava. Ao todo, Cortázar enviou 94 correspondências para Francisco Porrúa, 16 para Mario Vargas Llosa e 25 para Roberto Fernández Retamar.

${ }^{3}$ Trabalhamos com os três volumes organizados por Aurora Bernárdez - viúva de Cortázar -, editados pela Alfaguara em 2000, são eles: Volume I (Cartas, 19371963); Volume II (Cartas, 1964-1968); e Volume III (Cartas, 1969-1983). São 1.838 páginas que incluem o prefácio de Saúl Yurkievich e os apêndices de Jaime Alazraki, Jean L. Andreau e Juan Carlos Onetti, sem contar o índice onomástico e as referências biográficas.

${ }^{4}$ (Cf. BOURDIEU, 2002).

${ }^{5}$ As ferramentas conceituais para pensar e fazer a história dos intelectuais, como propôe Sirinelli (1996), são as estruturas de sociabilidade, as noçôes de geração e 
as reconstituiçôes de itinerários. A partir das estruturas de sociabilidade —agrupamentos permanentes ou temporários, qualquer que seja seu grau de institucionalização, nos quais os intelectuais decidem por várias razôes participar -, podemos fazer uma abordagem retrospectiva que permita reencontrar as origens do despertar intelectual e político de um determinado sujeito. Contudo, como alerta Sirinelli, em toda microssociedade encontramos a atraçáo e a amizade e, ao contrário, a hostilidade, a rivalidade, a ruptura, a briga e o rancor, que também desempenham um papel importante no mundo intelectual.

${ }^{6}$ Cortázar nunca deu maiores explicaçóes sobre sua discordância com o peronismo. ${ }^{7}$ O poeta cubano Heberto Padilla recebeu o prêmio Casa de las Américas em 1967 e, em seguida, foi destituído do prêmio e expulso da União dos Escritores de Cuba por causa de suas opiniōes sobre a Revolução. Em 1971, Padilla foi preso e fez ou, como muitos afirmam, foi coagido a fazer - uma autocrítica, negando tudo que havia dito anteriormente. Isso desencadeou uma onda de protestos por parte de antigos aliados de Cuba, como, entre outros, Jean-Paul Sartre e Mario Vargas Llosa. ${ }^{8}$ Em dezoito de novembro de 1968, o jornal Le Monde reproduziu um telegrama enviado por seu correspondente em Havana, no qual ele denunciava a nova política cultural cubana e o que acontecia com Heberto Padilla.

${ }^{9}$ Escritor francês do século XIX.

${ }^{10}$ Diretor da revista de 1962 a 1969, quando foi trabalhar como jornalista em Paris. ${ }^{11}$ Apesar da recomendação, o livro Los impostores foi publicado pela Seix Barral com o título de La ciudad y los perros, em 1963. A Sudamericana publicou o romance somente em 1967.

${ }^{12}$ Nesse período, foram produzidos vários livros de alto valor literário que ganharam projeção internacional. $\mathrm{O}$ mítico boom, que se traduziu em uma produção bastante original nas letras latino-americanas, em especial dos romances, teve seu limite temporal circunscrito entre a década de 1960 e o início dos anos 70, em torno de escritores como Julio Cortázar, Gabriel García Márquez, Carlos Fuentes, Mario Vargas Llosa, Juan Carlos Onetti, Alejo Carpentier, Miguel Ángel Asturias, José Donoso, entre outros. (Cf. COSTA, 2013). Apesar de não ser muito preciso quanto ao seu início e final, José Donoso afirmou que o boom pode ter se iniciado em 1962 com o Congreso de Intelectuales de Concepción e com a publicaçáo de $L a$ ciudad y los perros, de autoria de Vargas Llosa, pela Seix Barral, e teria terminado por volta de 1972, por vários motivos, entre eles o "caso Padilla" e a dispersão dos intelectuais em torno de Cuba. (Cf. DONOSO, 1983).

${ }^{13}$ Em dezoito de novembro de 1968, o jornal Le Monde reproduziu um telegrama enviado por seu correspondente em Havana, no qual ele denunciava a nova política cultural cubana e o que acontecia com Heberto Padilla.

${ }^{14}$ Cortázar recomendou a Vargas Llosa que a carta fosse enviada o mais rápido possível para García Márquez, que também havia se comprometido a assiná-la.

${ }^{15}$ Não tivemos acesso às respostas de Vargas Llosa para Cortázar. 
${ }^{16}$ Em 1979, Cortázar provavelmente mudou de opinião, pois aceitou o convite para ministrar cursos e conferências na Universidade da Califórnia, em Berkeley, onde passou três longos meses. Mas como diria o próprio Cortázar: "De fato eu sou terrivelmente contraditório, embora náo tanto quanto a realidade à minha e à nossa volta”. (MOISÉS, 1987, p. 12).

${ }^{17}$ Cortázar correspondeu com Lezama Lima e Virgilio Piñera.

${ }^{18}$ Antón Arrufat dirigiu a revista de 1960 a 1965. A partir de 1965, passou a ser dirigida por Roberto Fernández Retamar, que permaneceu no cargo até 1989 e reassumiu a direção da revista em 1991.

${ }^{19}$ Esse texto passou, posteriormente, a fazer parte dos Diarios, incluídos na obra póstuma de Arguedas, El Zorro de arriba y el Zorro de abajo (1971).

${ }^{20}$ (CORTÁZAR In. CROCE, 2006).

${ }^{21}$ Carta enviada para a professora de francês Marcelle Duprat.

\section{Referências}

ARGUEDAS, José María. Primer diario. In: El Zorro de arriba y el Zorro de abajo. Lima: Editorial Horizonte, 1983.

BEZERRA, Carlos Eduardo; SILVA, Telma Maciel da. A correspondência de escritores brasileiros como fonte de pesquisa para os estudos literários e históricos. Historiae, Rio Grande, n. 1, v. 1, 2010, p. 61-74.

BOURDIEU, Pierre. Campo de poder, campo intelectual: itinerário de un concepto. Buenos Aires: Editorial Montressor, 2002.

BOUVET, Nora. La escritura epistolar. Buenos Aires: Eudeba, 2006.

CORTÁZAR, Julio. Cartas (1937-1963). Buenos Aires: Alfaguara, 2000.

. Cartas (1964-1968). Buenos Aires: Alfaguara, 2000.

. Cartas (1969-1983). Buenos Aires: Alfaguara, 2000.

. Obra crítica. Rio de Janeiro: Civilização Brasileira, 1998, vol. 3.

. Creador solitario. Life en espanhol, Nueva York, 07 de abril de 1969. In:

CROCE, Marcela (Comp.) Polémicas intelectuales en América Latina. Del "meridiano intelectual" ao caso Padilla (1927-1971). Buenos Aires, 2006.

COSTA, Adriane Vidal. Intelectuais, politica e literatura na América Latina: o debate sobre revolução e socialismo em Cortázar, García Márquez e Vargas Llosa. São Paulo: Alameda Editorial, 2013.

DE DIEGO, José Luis. Cortázar y sus editores Orbis Tertius, v. 14. n. 15, 2009, p. 
1-12. Disponível em: http://www.memoria.fahce.unlp.edu.ar/art_revistas/pr.4197/ pr.4197.pdf. Acesso em 15 jul. 2015.

DEVÉS VALDÉS, Eduardo. Redes intelectuales en América Latina. Santiago de Chile: IDEA/Universidad de Santiago de Chile, 2007.

DOLL CASTILLO, Darcie. La carta privada como práctica discursiva: algunos rasgos característicos. Signos, 2002, v. 35, n. 51/52, p. 33-57.

DONOSO, José. História personal del “boom”. Barcelona: Seix Barral, 1983.

GILMAN, Claudia. Entre la pluma e el fusil: debates y dilemas del escritor revolucionario en América Latina. Buenos Aires: Siglo XXI, 2003.

GOMES, Ângela de Castro (Org.). Escrita de si, escrita da História. Rio de Janeiro: Editora FGV, 2004.

HINTZE, Gloria; ZANDANEL, María Antonia. Algunas nociones sobre el género epistolar a propósito de las cartas de Francisco Romero. Cuyo. v.29, n. 2, p. 13-33, 2012.

MESTRE SANCHIS, Antonio. La carta, fuente de conocimiento Histórico. Revista de História Moderna. Universidad de Valência, n. 18, 2000, p. 15-26.

MOISÉS, Carlo Felipe. Júlio Cortázar: ficção e realidade. Jornal de Letras, Artes e Ideias. Paço de Arcos (Portugal), n. 262, julho de 1987.

MONTAÑES, Amanda Perez. Vozes do exilio e suas manifestaçôes nas narrativas de Julio Cortázar e Marta Traba. 204 f. Tese - Programa de Pós-Graduação Interdisciplinar em Ciências Humanas, Universidade Federal de Santa Catarina, 2006.

MORAES, Marcos Antonio de (Org.). Correspondência de Mário de Andrade e Manuel Bandeira. São Paulo: Instituto de Estudos Brasileiros, Universidade de São Paulo, 2001. MORAÑA, Mabel. Territorialidad y forasterismo: la polémica Arguedas/Cortázar revisitada. In: FRANCO, Sergio (Org.). José María Arguedas: hacia una poética migrante. Pittsburgh: Universidad de Pittsburgh, 2006.

MOREJÓN ARNAIZ, Idalia. Politica e polêmica na América Latina: Casa de las Américas e Mundo Nuevo. 326 f. (Tese). Programa em Integração da América Latina, USP, São Paulo, 2004.

NAVARRO, Javier. Sociabilidad e historiografía: trayectorias, perspectivas y retos. Saitabe. Valencia, 2006, p. 99-119.

RODRÍGUEZ MONEGAL, Emir. Madurez de Vargas Llosa. Mundo Nuevo, n. 3, Paris, setembro de 1966, p. 62-72.

SALDÍVAR, Dasso. Gabriel García Márquez: viagem à semente. Rio de Janeiro: Record, 2000. 
História, política e literatura na escrita epistolar de Júlio Cortázar

SETTI, Ricardo. Conversa com Vargas Llosa. São Paulo: Brasiliense, 1986.

SIRINELLI, Jean-François. Os intelectuais. In: RÉMOND, René (Org.). Por uma história política. Rio de Janeiro: Editora UFRJ, 1996.

SYLVIE, Protin. Pari(s): la apuesta del Cortázar traductor. Cuadernos Americanos, $n^{\circ}$ 658, abril de 2005, p. 33-38.

D VARGas lLOSA, Mario. García Márquez: história de un deicidio. Barcelona: Barral Editores, 1971.

VENANCIO, Giselle Martins. Na trama do arquivo: a trajetória de Oliveira Vianna. 2003. Tese (Doutorado) - Universidade Federal do Rio de Janeiro, Rio de Janeiro.

Recebido em: 16/ 12/ 2015

Aprovado em: 21/ 03/ 2016 